\title{
The Anti-Communist Resistance in the Făgăraș Mountains (Romania) as a Challenge for Social Memory and an Exercise of Critical Thinking
}

\author{
Daniela Sorea $^{1}$ - Ana-Maria Bolborici ${ }^{2}$ \\ Faculty of Sociology and Communication, Transilvania University, Brasov

\begin{abstract}
The Anti-Communist Resistance in the Făgăraș Mountains (Romania) as a Challenge for Social Memory and an Exercise of Critical Thinking. Social memory is dynamic, adaptable to the ensemble of group perceptions on the present. In the first decade after WWII there were numerous active anti-communist armed resistance groups in the Romanian mountains. The most powerful resistance groups operated on the southern and northern sides of the Făgăras Mountains. According to the results of exploratory research conducted in 2020 the representations of the anti-communist resistance in the mountains in Romanian young people's memories are feeble. Retrieving representations of the resistance is useful as critical exercise in understanding history, as source of identity comfort and as part of the lesson on totalitarianism.

Sociológia 2021, Vol. 53 (No. 3: 266-286)

https://doi.org/10.31577/sociologia.2021.53.3.10
\end{abstract}

Key words: Anti-Communist movement; resistance; social memory; critical thinking; identity

\section{Introduction}

Social representations of historical events reflect the way a community views the latter, as well as their political and social context. Social representations become part of social memory. Social memory contributes to molding the identity of community members, as well as their sense of belonging to the community. Social memory leaves marks on future social representations and on the way a community responds to the challenges of history. The past shapes the present and prefigures the future. At the same time, social memory is under permanent reconfiguration. The present renders significance to the past.

Similarly to other former Communist countries in Central and Eastern Europe, Romania has been through two major changes in its political regime since WWII. Therefore, its recent history provides plenty of opportunities to highlight the relationship between social memory and the political context. Students' interest in history as a subject matter taught in schools is declining (Mihalache 2012). One of the solutions suggested to revitalize their interest is to shape their critical historical thinking and exercise it on the representations of the past.

\footnotetext{
1 Address: Daniela Sorea, PhD., Transilvania University of Brașov, Faculty of Sociology and Communication, Brasov, 500030, B-dul. Eroilor, nr. 25, Romania. E-mail: sorea.daniela@unitbv.ro

2 Address: Ana-Maria Bolborici, PhD., Transilvania University of Brașov, Faculty of Sociology and Communication, Brasov, 500030, B-dul. Eroilor, nr. 25. Romania. E-mail: ana.bolborici@unitbv.ro
} 
An exploratory research on the Romanian students' representations about the resistance movement in the Făgăraș Mountains conducted in 2020 showed young people's poor knowledge of the subject. The way this piece of Romanian contemporary history was adopted into social memory reflects, as an abductive inference based conclusion, the impact the instauration and consolidation of the Communist regime had on Romanian people. We believe the resistance in the mountains along with the reasons for its imperfect retrieval in social memory can be valuable topics for a critical historical thinking exercise. The exercise can improve the self-image of young Romanians and contributes to the common European lesson on the dangers of totalitarianism.

The concepts of "social representation" and "social memory" are used by this paper from a constructionist perspective. Before presenting the design and research results, we will outline the main connotations of these concepts.

\section{Social representations and their dependence on the historical context}

According to Serge Moscovici, social representations are coherent sets of values, ideas and practices allowing individuals to orient themselves and take hold of the environment, as well as to communicate with one another and integrate in the community (Moscovici 1973; 1976). Social representations are parts of the social construct of reality. Social representations leave cultural marks on inter-human relations, generating expectations and anticipations (Neculau 1996). The complete, coherent and comprehensive story about the collective history conveyed by social representations is not necessarily based on historiography, but is a reconstruction of the past in accordance with the symbols, myths, models of the group's culture (Bar-Tal 2014).The object of social representations is built by communities in order to make their members behavior and communication more efficient (Andersén - Andersén 2014, Bratu 2014). By mediating communication, social representations facilitate the adoption of ideological and cultural models and ensure the dissemination of ideas and behavioral styles. Different human groups may have different representations of the same object (Andersén - Andersén 2014). The same historical truth may have multiple facets (Bolborici 2017).

Structurally, social representations have a central core and peripheral elements (Abric 1994). The central core organizes the representation, determines its significance and assigns its meaning. The peripheral system manages the fit between the social representation and reality. Its components are the flexible part of representations and act as an interface between the central core (which they protect) and the world. Information that is sufficiently prominent to modify the central core can be incorporated in the peripheral system, changing the significance of the representation (Neculau 1996). 
Social representations are continuously fed by the social environment, collective imagination, and individual cultural acquisitions. Therefore, they are sensitive to historical evolution and subjected to ideological pressure. For example, immediately after WWII, the crimes of the Nazis and people's collaboration with the Nazi regime were taboo subjects for a long time, while East German people reinvented themselves as victims of the Nazi regime. These are different ways of managing the same traumatic memories (Kansteiner 2006).

Social memory stores social representations. History is institutionalized memory (Fogu - Kansteiner 2006). According to Lambek (2003), "History is memory inscribed, codified, authorized; memory is history embodied, imagined, enacted, enlivened" (p. 212).

On the other hand, Pierre Nora (1989) believes that while memory is the live dialogue between the present and the past, history is a static, incomplete and selective reconstruction meant to correct the past. History is the opposite of memory, the two are mutually hostile means to relate to the past.

Between the two facets of the relationship of history with memory (one of taking over in history the emotionless memory contents, and the other of selective, corrective rebuilding memory in history), the preservation of representations for as long and as correct as possible (i.e. close to the reference point) by social memory has an identity stake. Social memory, supporting group collective identity (Fogu - Kansteiner 2006; Palmberger 2016), the identity of the self, and national identity (Zembylas - Karahasan 2017), also acts as a cohesive factor (Šubrt 2011) and as a source of resistance to the challenges of history.

\section{The political usefulness of social memory}

Memory is the current knowledge of the past (Halbwachs 1958). Its content is rebuilt and not neutrally preserved. The contents of memory are tributary to memorization policies (Fogu - Kansteiner 2006). The meaning attributed to past events depends on the political and historical context of the present (Palmberger 2016). The interests of collectivities reorganize the memories of their members, indicates Chelcea (1996). Thus, memories are learnt.

During its evolution towards postmodernism, memory lost its spontaneity and simplicity and became archive and debt. There are lieux de mémoire because livelihood is no longer possible in the real environment of memory, as Nora (1989) notes.

The reorganization of social memory can be politically used (Golden, 2005). It works along with the rewriting of history as leverages for gaining legitimacy and consolidating power. The attention received by social memory in politics is just the result of the relation between the control of the past and the legitimization of political regimes (Brunnbauer 2012, Šubrt 2011). Social memories play an important role in building ideologies and in configuring social preferences 
(Bratu 2014). Every political regime uses them to serve its interests. For example, the disappearance of institutions, hierarchies, old social and economic relations was presented and credited as the foundation of Soviet Russia, the most liberated country in the world, a red Paradise (Wydra 2012). West Germany was accepted as a partner in the anti-communist block together with its former war enemies, and as of 1995 war memory has become common European remembrance of abuses against humanity, the legitimacy of the European Union being more important than the confrontations in the war (Kansteiner 2006). When the Communists assumed power, they programmatically erased the positive representations of the times before the Communist regime from social memory (Ciobanu 2015). In Bucharest, the museum called the Museum of the Romanian Communist Party before 1989 was (re)branded as the Museum of the Romanian Peasant after 1989. The prison from Doftana, which under the Communist regime used to be a museum dedicated to those who had fought for Communist ideals, is no longer a tourist attraction nowadays and was left to go derelict. Instead, the prison from Sighetu Marmatiei was brought into the limelight and turned into a museum honoring the memory of the anti-Communist fighters. And history goes on. The post-communist transition period had its own victims in Eastern Europe, which should be counted alongside the victims of Communism and for which the guilty should be identified. However, that is still an uncomfortable topic, and its approach would go against the current trend celebrating the victory won by the liberal democracy (Pusca 2014).

\section{The anti-communist resistance movement in the Făgăraș Mountains}

In 1946 Romania organized elections. With the support of the Russian troops stationed in the country the Communists won the elections by fraud (Cioroianu 2005; Voicu-Arnăuțoiu 2009; Petrescu 2012; Miroiu 2014). The Romanians were surprised by the results because there were few Communist supporters among the people. Then, they believed that Western democratic powers would not tolerate the breach of democracy and would interfere to re-establish the natural order.

Some of the military officers of the Romanian army viewed it as their duty to lay the ground for Western (especially US) intervention (Coman 2004). They began to gather weapons, store them in safe places, organize support networks with trustworthy locals and even train these. That is how the anti-communist resistance movement emerged in the middle of the " 40 s.

However, Western military support did not materialize. Meanwhile, the newly sworn Communist regime consolidated its power. Many officers were forced to retire, then they were accused of anti-Soviet attitude for having participated in the military campaign conducted in the East during WWII. 
All local leaders, politicians, professors, priests, teachers and wealthy peasants were considered dangerous for a regime that could not rely on the genuine sympathy of the people. Meanwhile, the Communist regime began to increase the power of the Security (Securitate in Romanian), its instrument of repression. In this context, what had started as a patriotic movement meant to lay the groundwork for the rescue intervention of Western democratic powers gradually gained increased personal stakes for those involved. That was a point of no return for them.

After the first confrontations with Security forces, the group members had to choose between surrendering to stand trial as enemies of the people, being rehabilitated in exchange for betraying their comrades, or fighting to the end. Most of them chose the latter. They put up resistance until the end of the 50s (1958) with the aid of the village dwellers at the bottom of the mountains. The latter were severely punished for having hosted, supplied food, medicine and news to the fighters (Dobrincu 2007; Ionițoiu 1993). With no possibility to hide, they were also intimidated, arrested, put under investigation, tortured, convicted to prison or death.

The Security slowly annihilated the resistance movement by resorting to armed confrontation, infiltration, betrayal, arrests, and executions. Many of the resistance fighters and supporters died in prison. Mihalcea and Stănescu (2014) estimate the number of those convicted to prison for political reasons under the Communist regime at around 200,000. The criminal records of 93,000 of these have been found. At the beginning of 1963 there were 16,327 people imprisoned for political reasons (Deletant 2001). In 1963 and 1964 pardon decrees were issued for them, followed by surveillance instructions for their day-to-day life. Survivors returned to a world where social hierarchies had been upturned. Consequently, outside their circle of close friends they were viewed as weird or incapable of adaptation, and were marginalized. It was a world in which Communist propaganda would persistently call them bandits or people's enemiesthat would push for the change of the official representation of the resistance movement.

The Făgăraș Mountains is the highest mountain range in the Meridional Carpathians. The group Arsenescu-Arnăuțoiu, known as The Outlaws of Muscel, was the most important resistance group that acted on the southern slope of the mountain. Colonel Gheorghe Arsenescu was a trained military, General Staff commandant for Division III on the Eastern front (Petrescu, 2012). After the war he was removed from the armed forces at the age of 39. Toma Arnăuţoiu had been a lieutenant of cavalry in the Royal Guard and had been forced to retire. The impressive local support (many locals did not yield to torture, protecting the fighters) was the result of the prestige colonel Arsenescu 
and the teacher Iancu Arnăuțoiu, father of the fighting brothers Toma and Petru, had.

Many girls and women followed their fathers, lovers, brothers, husbands or sons to the mountains. Toma Arnăuțoiu had his daughter born in one of the fighters' hideouts. The child was given up for adoption after the arrest of her parents and she only found out about them after 1989 (Voicu-Arnăuțoiu 2009).

The Arnăuțoiu brothers were betrayed and caught in 1958. They were executed in 1959. Colonel Arsenescu was captured in 1961 and executed in 1962.

The group headed by Ion Gavrilă Ogoranu and known as the Făgăraș Carpathian Group operated on the northern slope of the Făgăraș Mountains. Unlike Arsenescu and Arnăuțoiu who were military, the core of this northern group was made of students or young college graduates, who had been high school colleagues in "Radu Negru" high school în Făgăraș. In the aforementioned high school there had been a powerful Brotherhood of the Cross group. Brotherhoods were the youth organizations of the Legionary Movement, the Archangel Michael Legion. The latter was an organization of fascist orientation that activated in Romania between 1927 - 1941. The movement's ideology also combined nationalism, Eastern Orthodox ideas and anti-Semitism. The Iron Guard was the paramilitary branch of the Legion. The Archangel Michael Legion was in power between September 1940 and January 1941 as part of the government led by Marshall Ion Antonescu. During that time period the anti-Semitic laws that had already been issued in Romania were enforced. Between the $21^{\text {st }}$ and the $23^{\text {rd }}$ of January 1941 the legionnaires attempted a coup d'état that was later referred to as the Legionary rebellion. They were put down by Ion Antonescu with the help of the armed forces. Subsequently, the Legion was formally destructured and its leadership managed to take refuge in Germany. During the rebellion the Bucharest Pogrom occurred and around two thousand Jews from the two Jewish neighborhoods of Bucharest were beaten, raped and tortured (Clark 2015).

In 1947 Ion Gavrilă Ogoranu was a student in Cluj (the most important university center from Transylvania) and, according to him (apud Dobrincu 2007), headed the Brotherhoods of the Cross in Transylvania. In 1946 he had participated in the confrontations between the students from Cluj and the police forces serving the new regime (Coman 2004). In May 1949, "The Old Man" (as he was nicknamed for his advising skills) went up the mountain along with 13 young people. Four of those had been members of the Legion, half of the others had already been members of the Brotherhood of the Cross group operating in "Radu Negru" High School in Făgăraș (they were around eleven years old in 1941), while the other half of group members were apolitical (Hașu 2017). 
They were all familiar with the mountain, where they felt like home for it had been the place where they had grown up. They tried to encourage the people in the region that things would get back to normal, which meant the removal of Communism. Some of the group's members had been at war, others (Ion Gavrilă Ogoranu was one of these) had graduated from the military school and acquired books on guerilla war. Former officers supplied them with weapons and equipment. They had raised huts where they held supplies of food and weapons.

They were never the first to open fire against the Security troops, nor did they display violence towards shepherds, forest workers or tourists with whom they came in contact (Dobrincu 2007).

The first actions taken by the Security against Ion Gavrilă Ogoranu's group were poorly organized. The troops deployed in the area were too numerous for apprehending a small number of people, the signals they used were inappropriate and unveiled their position. It is anecdotal the use of a cuckoo bird's song as a signal in August when it was common knowledge among the locals that the bird had stopped singing a while before (Dobrincu 2007). Some young officers were impressed by the moral values and the military training of the fighters they encountered (Dobrincu 2007) and tacitly showed understanding for them (Coman 2004).

Under such circumstances, an aura of legend around the resistance movement organized in the mountains emerged. The rumors had it that there were thousands of fighters, that the authorities could not manage them, that they had special weapons brought from Western countries by planes which were landing on the meadows in the mountains, and that they had dug trenches in the mountain stone (Dobrincu 2007).

The strategy of the Security gradually improved. The communities at the bottom of the mountain were under psychological and military siege (Coman, 2004). As of 1952 Security described Ogoranu's group as more dangerous than the Arsenescu-Arnăuțoiu group. According to its documents, it was "solely made of intellectuals" who were contributing to "an unhealthy state of mind among the people" (Dobrincu 2007: 465).

In 1956 most of the surviving fighters and their close supporters of them were drawn into a race, with the help of one of the members of the support network, whom they had known for a long time. In 1957 they went to trial and were sentenced to death or life imprisonment.

Ion Gavrilă Ogoranu was only arrested in 1976, after the political prisoners from Romania had already been released (in 1964) and the crimes for which he had been convicted in absentia became prescribed. The number of the families oppressed on suspicion of having provided support to the fighters amounted to more than 1,000 (Dobrincu 2007). 


\section{Students' representations of the anti-communist resistance movement in the Făgăraș Mountains}

We wanted to explore the way the armed anti-communist resistance movement from the Făgăraș Mountains as part of Romania's recent history has been adopted in social memory. Thus, in October 2019 we asked a group of students from Transylvania University of Brașov, Romania, to write about their knowledge on the topic.

\section{Methodological details}

The students included in the research project were undergraduates in Sociology and Human Resources study programs: 52 of them enrolled in their first year of study, 15 sophomores and 36 third year students. They came from the Braşov County (34) and from other Romanian counties (69). There were 103 respondents, 91 female and 12 male. The gender imbalance of the sample was the result of the gender profile of the specializations.

The question students had to answer was: What do you know about the resistance movement from the Făgăraș Mountains?, and they were also asked to indicate the source of their knowledge on the subject. They were given $30 \mathrm{~min}$ utes to answer and encouraged to detail their answers. The term anti-communist was not included in the question in order not to influence the results with answers deemed desirable (Rotariu - Ilut 2001) or with improvisations. We reckoned that for the respondents who already knew about the topic, the phrase the resistance movement from the Făgăraş Mountains would already carry enough meaning, since the anti-communist dimension is its first connotation and a defining feature.

We analyzed the answers thematically with NVivo10. We considered that thematic analysis as a method is useful as a result of its flexibility, independence from a given theoretical framework, and its applicability in the case of under-researched areas (Braun - Clarke 2006). The answers were translated in English before feeding them into NVivo.

\section{Research results}

The categories and the subcategories identified upon analyzing the answers are presented in Table 1. They are organized in decreasing order by the number of answers in which they appear. This number and the number of codes that each category and subcategory subsumes are indicated in parentheses (n1/n2).

The first two subcategories include explicit references to Communism. The other subcategories of the Anti-communist movement category indicate relevant features of the resistance movement organized in the Făgăraș Mountains. The Partisans subcategory has as its reference term the name of partizani (Romanian for partisans) used to refer to the fighters in the mountains. The term was 
used in Romania because of its association with the anti-fascist partisans from Greece and Yugoslavia. In this respect, the term did not include any connotations related to its original meaning of Marxist revolutionary fighter as employed during the Civil War in Russia in 1917 (Coman 2004).

Table 1: What do you know about the resistance movement from the Făgăraș Mountains?

\begin{tabular}{|c|c|}
\hline Categories (n1/n2) & Subcategories (n1) \\
\hline \multicolumn{2}{|l|}{ I don't know (48/48) } \\
\hline \multirow[t]{2}{*}{ Anti-communist movement $(33 / 84)$} & $\begin{array}{l}\text {-"Against communism" as an explicite attribute (23) } \\
\text {-During the communist period (11) } \\
\text {-Hiding places in the mountains (9) } \\
\text {-Young people (7) } \\
\text {-Disobedience (5) } \\
\text {-Self-isolation as a form of revolt (4) } \\
\text {-Waiting in vain for the Anglo-Americans (3) } \\
\text {-Pseudo-information (2) } \\
\text {-For freedom (2) } \\
\text {-Partisans (2) } \\
\text {--It lasted several years (2) } \\
\text {-They were defeated (2) } \\
\text {-Ion Gavrilă Ogoranu was the leader (2) } \\
\text {-Others (7) }\end{array}$ \\
\hline & $\begin{array}{l}\text {-Protect the environment (7) } \\
\text {-Disagreement on illegal deforestation (4) } \\
\text {-Promoting mountain tourism (4) } \\
\text {-An opportunity to develop the area (3) } \\
\text {-Resources (1) } \\
\text {-A series of dams (1) }\end{array}$ \\
\hline Other answers $(8 / 8)$ & $\begin{array}{l}\text {-A closed society (4) } \\
\text {-People's mobility (2) } \\
\text {-An old and difficult case (1) } \\
\text {-Movement of mountain rocks (1) }\end{array}$ \\
\hline
\end{tabular}

The Others subcategory includes seven different themes that appear only once: Fights, In film and reportage, Tortured families, Cooperativization was a cause, In Bucovina as well, Wanted by Militia, Several cores.

Among the subcategories Development of the mountain area category are topical themes for the Romanian mass-media (Disagreement on illegal deforestation), as well as for the sustainable activities conducted by the NGOs with which schools cooperate (Protect the environment, Promoting mountain tourism, An opportunity to develop the area, Resources). These are topics of interest for Romanians. In this respect, the size of deforestation is frequently discussed as worrisome and the civic initiatives aimed at stopping the phenomenon are praised.

The subcategories included in the composite category of Other answers contain other opinions about what the resistance movement might mean. They 
are classified separately because they do not specifically refer to the development of the mountainous area.

Therefore (Figure 1), the number of responding students who do not know what the phrase resistance movement in the Făgăraș Mountains refers to (70) is considerably higher than the number of those who do know (they organized their answers around the anti-communist dimension of the movement: 33 ).

Figure 1: Categories of answers

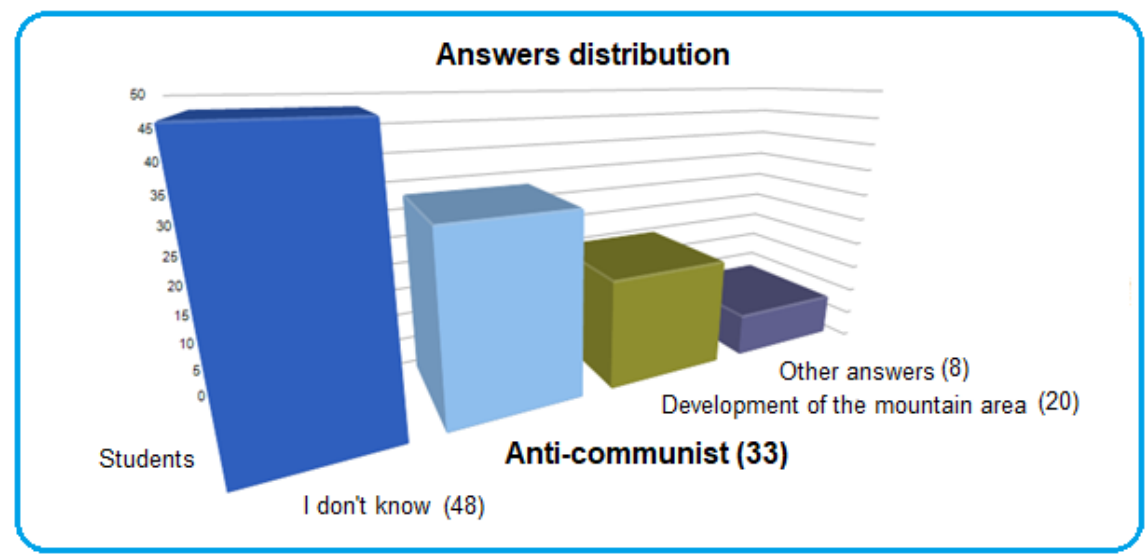

Figure 2: The distribution of students' answers by their counties of origin

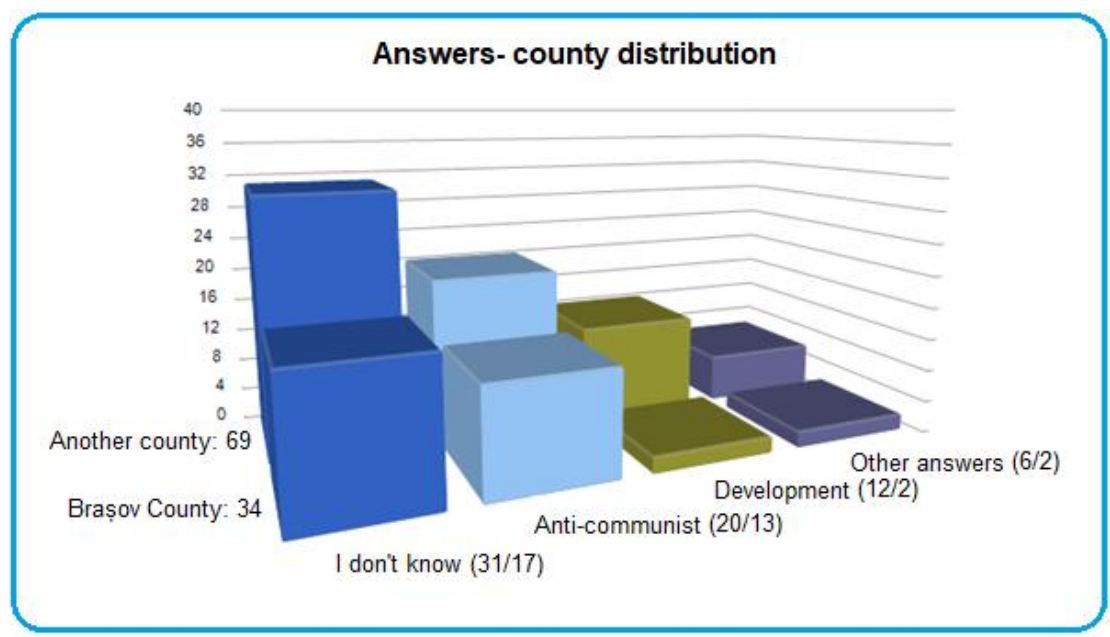

Sociológia 53, 2021, No. 3 
The distribution of the answers provided by the students from Braşov County and by those from other counties follows a similar trend.

The increased knowledge on the anti-communist resistance movement in the mountains showed by the students who had been born in Brașov compared to those coming from other counties, as well as the role of their families in acquiring it, shows the local character of an intergenerational transfer of representations on the resistance movement, mostly within the families and communities who had been directly affected by the phenomenon.

In the case of the other categories of answers (different from I don't know) the students indicated the mass-media and the school as sources of information.

Figure 3: The sources of knowledge on the anti-communist dimension of the resistance movement

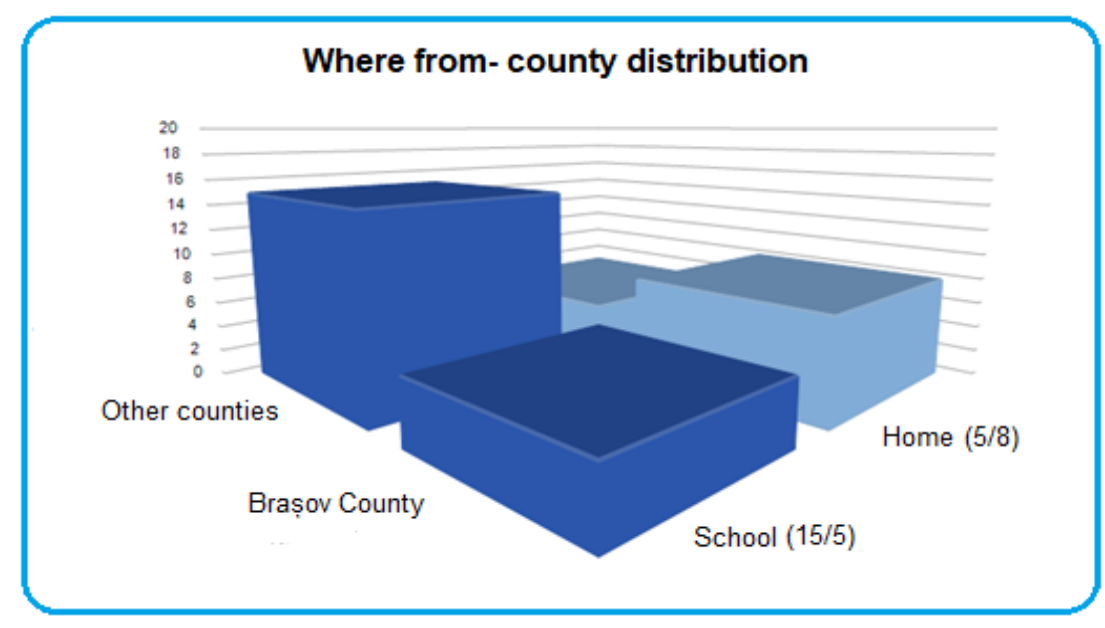

The research did not highlight any differences based on the university specialization or on gender.

In summary, out of the overall number of students asked about the resistance movement, some (33) indicated its anti-communist dimension, others (48) simply replied I don't know, whereas the rest referred to the development of the mountainous area (14) or to other aspects associated with the mountains (8). The research results suggest the poor representation of this part of Romanian contemporary history in students' memory.

The respondents were students in socio-humanities specializations in Braşov. That means they were very close to the area of the anti-communist resistance movement on the northern slide of the Făgăraș Mountains. Such circumstances should have increased their interest in the recent history of Romania. They should have known more about the episode than the majority of 
the other Romanian students (except for those in History), or than the pupils and youth who decided not to take higher education. In such a context, the research results indicate (by extrapolation and with the reserve of the exploratory nature of the research) that the social representation of the anti-communist resistance movement organized in the Făgăraș Mountains is on the verge of disappearance from Romanians' social memory. It is meaningful for the adult generation (Dobrincu 2007), whereas it is almost deprived of significance for the young generation. The interest for this part of the Romanian national history has been appropriated by young people and is maintained only sporadically either at a personal level (within family and/or community) or from an educational perspective (as interest in a topic that was well approached by a teacher of History).

\section{Discussions}

The anti-communist resistance movement in the Făgăraș Mountains and its support for exercising critical historical thinking

Carretero (2017) emphasizes two different approaches to historical education: a Romantic approach aiming at positively representing the past, the present and the future of the (local or national) social group, as well as the group's acceptance of the country's political history, and the Enlightened perspective focusing on building a critical capacity to approach historical events, including those from one's own community. Carretero believes that the Enlightened perspective may resuscitate students' interest in History. Based on this perspective students are taught historiographical procedures and encouraged to discuss history topics. Thus, students learn that the solutions to the problems are debatable and that the past can be interpreted from different perspectives. Additionally, they learn to strike out idealized representations, and view heroes as complex characters acting under specific historical circumstances. Consequently, they should understand that historical representations are dynamic interpretations of the past which can suffer changes depending on research results and that the moral judgments on historical events are not definitive (Carretero 2017). Psaltis, Carretero and Čehajić-Clancy (2017) promote this didactical approach to history as transformative history teaching. The theme of the anticommunist resistance movement in the Făgăraș Mountains matches such an approach, it offers generous support for the exercise of critical historical thinking and for the understanding of the threats raised when simplifying history.

Official information on the length of the anti-communist resistance movement in Romania were made available to the public only after the Securitate files were declassified, long after 1989. In the first decades after Communism came to power, the stories about resistance fighters and their local supporters were furtively whispered. However, the taboo character of the subject increased 
the popularity of resistance fighters and consolidated their heroic aura that Coman (2004) refers to.

After 1989 the theme of the resistance organized in the mountains was politically capitalized. Domestically, it was a source of political capital for the "historical" parties (they were old enemies of the Communists, had been defeated during the frauded elections of 1946 and re-organized after 1989). Internationally, it was used in the context of Romania's accession to the European Union as a theme underlining the continuity of Western democratic tradition (Ciobanu 2015). It became a tool employed to glorify national pride (Liiceanu 2003) and the core of a myth on the heroic anti-communist and anti-Sovietic movement which had been widely supported by the entire population of the country (Ciobanu 2015). The Report of the Presidential Commission for the Study of the Communist Dictatorship in Romania (2006) presents the resistance movement as a heroic episode and recommends its integration into the national collective memory.

However, the personal reasons pushing people to go into the mountains were diverse (Ciobanu 2015). For many of them the mountain was the solution to a very real survival problem. It was not always a matter of free personal decisions and/or assuming the consequences of political options different from the official agenda. The representation of the opposition between the anticommunist fighters patriots on the one hand, and the treacherous authorities making a pact with the Soviet occupant, on the other hand, is simplistic.

At the beginning of the 20th century a lot of Romanians left from Făgăraș County and from other parts of Transylvania to America. They worked there for several years and then came back with money, built houses, bought land and started small businesses. The contact of the people from Făgăraș with America might have additionally fueled their pro-American attitude, and the long-honed hope that the Americans would not tolerate the fraud in the elections and the Communists' abusive power takeover in Romania.

Another feature of the villages from Făgăraș County might be reflected in the characteristics of the resistance group operating on the northern side of the mountain. It is the annual organization of lads' groups in every village. The main role of these groups is to carol at Christmas, but their organization is almost military-like and their attributes related to preserving the observance of the rules within the community would span all throughout the year well after the end of the war (Herseni 1977). Between Christmas Eve and St. John the Baptist (celebrated on 7 January) the members of the group leave and manage their whereabouts together, respecting quite strict regulations. Research dated 2018 indicates the group of lads as the main resource of intangible cultural heritage in the area (Sorea - Csesznek 2020). The efficiency shown by the group run by Ion Gavrilă Ogoranu and made up of young people might have 
also been the result of their experience as members in the caroling lads groups organized in their villages of origin.

All these nuances and features make the theme of the anti-communist resistance valuable for the exercises of transformative history teaching. We believe that the former membership of the Brotherhood of the Cross group operating in "Radu Negru" High School of many of the fighters from the Făgăraș Carpathian Group, namely their legionary youth, can also be used separately in critical historical thinking exercises. Aspirers to Brotherhood membership were industrious pupils and they were encouraged to discover and correct their flaws (Gavrilă Ogoranu 2004). The actions undertaken by the resistance group headed by Ion Gavrilă Ogoranu were programmatically driven by military honor and Christian moral standards (Dobrincu 2007). However, the Archangel Michael Legion was accused of crimes against the Jews and claimed responsibility for several political assassinations like the one of Armand Călinescu, standing prime minister in 1939, or the killing of the historian Nicolae Iorga in 1940. To make the critical historical thinking exercise even more interesting, the last two murders were vengeance for the killing of the Legion's leader as well as of several prominent figures of the organization while imprisoned, for which the prime minister and Iorga, in particular, were considered morally responsible. Legionary supporters claim to this day that the killing of the Jews was provocation for which they do not take responsibility (Coja 2015). What is more, according to them, the accusations brought to the Iron Guard on this matter were withdrawn during the Nürnberg Trials, while at the end of a libel trial conducted in Paris in 1973 the Court ruled in favor of a legionary priest, called "war criminal" by the publication „Le droit de vivre", based on his membership in the Legion - an all the more powerful argument that such a trial brings justice to the Archangel Michael Legion (Coja 2015). The promoting of legionary ideas, concepts or doctrines is sanctioned in Romania by Law no. 217/2015. On the other hand, Communism was officially condemned in Romania in 2006. The report presented at the end of that year by the Presidential Commission for the Study of the Communist Dictatorship in Romania is about "recovering memory, but also identifying responsibilities" (Comisia 2006: 10). The Report states that political affiliation in the resistance was diverse and, as we have already highlighted, characterizes the anti-communist movement as heroic.

It would be challenging for History teachers to talk to their students about the heroic and laudable anti-communist actions of young people whose legionary past is condemnable. Transformative history teaching could transform such a challenge into a useful exercise.

The rather small number of respondents indicating school as the source of their knowledge on the resistance movement in the mountains (20 students of a

Sociológia 53, 2021, No. 3 
total of 33 mentioning the anti-communist character of the movement) suggests the poor coverage of this topic during History classes. We believe the main reason underlying both young and older History teachers' reluctance towards approaching the topic is its overlap with information on the Legionary Movement- a rather sensitive issue from a political perspective. That unveils the utility of transformative history teaching. The latter allows for a comforting approach to issues by encouraging free debate on the theme of resistance. That is all the more important since the lack of information on the anti-communist resistance movement implicitly signals that the information on the status of Fascism in Romania is scarce to none. The members of the pro-fascist organizations had been ever since the latter's establishment radical opponents of the Soviet Union in Romania (Miroiu 2014). The increased use of team based project development and of the Internet as a source of information for project writing in pre-university education (Sorea et al., 2011; Sorea - Repanovici 2020; Sorea et al. 2021) supports transformative history teaching. Students' interest stimulated in this way and teachers' discernment may transfer the topic from the area of mandatory history curriculum to that of popular history.

There have been discussions about the necessity of reforming the educational system in Romania for a while. The reform could include the efforts of resistance memory retrieval. An option that we deem simple and less costly is that of approaching the anti-communist resistance as part of optional disciplines on local history. The decision on which optional disciplines to put on the educational offer is decentralized. Lessons on the resistance groups taught in the areas where they operated would easily raise the interest of the students, and favor the inclusion of the topic into popular history.

The importance of the anti-communist dimension of the resistance movement in the Făgăraș Mountains

As previously highlighted, research results show an imperfect assimilation of the theme to the young generation. The respondents are not familiar with their parents' and grandparents' representations. The almost legendary aura of the fighters in the mountains does not cross the threshold of the next generation.

We reckon that capitalizing at a local level on the memories of the anticommunist resistance movement in the mountains would increase the efficiency of retrieving this specific historical episode in social memory. There are several community museums, mostly ethnographic, in Făgăraş Land. They could host exhibits dedicated to the anti-communist fighters, namely grandparents, parents, other relatives or friends of the locals. That could thus contribute to improving the self-representation of community members. Additionally, sharing memory makes community members responsible for preserving common remembrances (Fishel 2015). But the topic on the resistance organized in 
the mountains is also a sensitive topic in the villages at the bottom of the mountain. The people of Făgăraș are still reluctant to approach the topic. That is a remnant of the times when any reference to that could have become a matter of life and death (Sorea - Csesznek 2020), as well as a feature of an area where many of the former high school students had been members of the legionary Brotherhood of the Cross groups.

Recalibrating social representations of the fighters in the mountains both in school and through local museum initiatives would simplify and diminish the effort to retrieve them as part of social memory.

Recalibration means transforming the anti-communist character of the resistance movement, which is its main historical defining feature (Coman 2005; Dobrincu 2007; Petrescu 2012; Miroiu 2014), into the central core of contemporary representations. The different motives that made the fighters take it to the mountains merged and crystalized as opposition towards the totalitarian regime. The fact that some of the resistance group members went up the mountains because they were hunted and threatened by the Communist authorities (Ciobanu 2015) only consolidates the anti-communist dimension of their actions. All of them took the full brunt of their opposition to the regime. On the other hand, the recalibration does not involve removing the other features of the movement. It overcomes the reluctance to approach the topic, opens the path in this respect and secures the support for debates over its multiple facets. In our opinion, to recalibrate is not to replace one biased perspective with an equally biased viewpoint. It is a means to switch from eluding a historical phenomenon to critically approaching it.

Representing the resistance in the mountains as mainly anti-communist would aid the teachers of History overcome the heroic-condemnable dilemma and encourage the locals in the Făgăraş Land assume recent history. It would unchain memories, stories and legends about the fighters in the mountains, facilitating their retrieval as part of the heritage. Additionally, it would complete and balance the European memory of totalitarianism which focuses on Nazism and the Holocaust in the West (Clarke 2014). As history proves it, all unlearned lessons are prone to being repeated. The Russian students born after the collapse of the Soviet Union have a positive perception of the Soviet period and experience the nostalgia of the Soviet past (Kasamara - Sorokina 2015). A 2015 study on terrorism shows that common Europeans are willing to sacrifice their civil rights in favor of increasing security (Grødeland 2015). These show that it would be advisable to remind Europeans of the impact of totalitarian regimes upon their countries in the middle of the twentieth century. The accession of Central and East European countries to the EU added the representations of Communism as developed by those who had directly experienced it to the common European memory of totalitarianism. These representations were 
built on specific national experiences (Clarke 2014). Nonetheless, the European Union aims to be unity in diversity. Consequently, the armed resistance organized in the Făgăraș Mountains is one of the chapters in the lesson on totalitarianism and, as a result, rightfully part of European memory.

\section{Conclusions}

Disregarding the part played by the anti-communist armed movement in Romanians' recent history does not benefit anyone. Nor does it show fairness towards the fighters in the mountains or towards nowadays' young people. Such an attitude is not equitable to the former because it implicitly accredits the representation promoted by Communist propaganda. The transformation of the entire anti-communist armed resistance into a taboo subject as a result of some of its members' legionary past is the result of an illegitimate extrapolation that almost removed the fighters in the mountains from social memory.

Disregarding the resistance in the mountains is unfair towards young people because it deprives them of a lesson on history dynamics, as well as on the relation between individual lives and great collective events, between the local and the universal context. Additionally, it is unfair because it limits young people's access to an intangible cultural heritage resource, which has an identity stake and strengthens the links between successive generations of a community. Cultural resources catalyze the interactions among community members and emphasize the sense of community belonging (Balfour et al. 2018).

We believe that opening the access to all the facets, nuances and features characterizing the remembrance of the resistance in the mountains is a sustainable approach to the topic. Thus, what is sanctionable will be penalized, and what is commendable will be given credit. By resorting to their own judgment and a stable axiological system, relying on available data, exercising their critical historical thinking in relation to sensitive topics, young people can avoid transforming the references to the resistance in the mountains into a failed history lesson. A sustainable approach to history changes the balance of forces modelling social memory. It diminishes the power of political factors (state, parties, ideologies) while expanding the importance of civil society and local identity.

\section{Limits of the research}

The respondents study socio-humanities and come from just one university center, namely from Brașov. Along with the research results we also presented the circumstances encouraging us to consider them valid for the majority of young Romanians. Nevertheless, the assertion that all Romanian young people know about the resistance movement in the Făgăraș Mountains just as little as 
the students from Braşov involved in the research is a hypothesis that still needs further investigation with a representative sample of respondents.

The sample used for the current research does not include a sufficient number of students from the other three counties where the groups in the Făgăraș Mountains operated. Therefore, the statement that the information on the resistance movement is transferred to young people through their families and communities is valid only for Brașov County. The same reason supports our belief that the reference point for most of the students' knowledgeable answers concerning the phrase the resistance movement in the Făgăraş Mountains is the Făgăraș Carpathian Group operating on the northern side of the mountain.

Daniela Sorea is Senior Lecturer at the Social Science and Communication Department of the Transilvania University of Brassov. She holds a PhD in Sociology and a master degree in Human Philosophy. She coordinated the local project CarPaTO - Mapping the intangible cultural heritage in Fagaras Land (2018), and the university team in the EfC project ACT-Active Telling, Active Learning to recover and enhance memories about WWII (2019). She published two books on contemporary religiosity and edited two volumes on war and communism in Romania. Her most recent scientific papers: The post-socialist city of Brașov: Challenges and perils (2018), The Der Alte Hildebrand Anecdote and the European Dimension of Romanian Folklore (2019), God, as the children of Romania draw It (2020, book chapter), The groups of caroling lads from Făgăraș Land (Romania) as niche tourism resource (2020, co-author Codrina Csesznek). Main research interests: Urban habitation, transmodernity and contemporary religiosity.

Ana-Maria Bolborici is a PhD Senior Lecturer and also Erasmus+ Coordinator at the University Transilvania of Brasov, Department of Social Sciences and Communication. She has two Bachelor degrees: in Political Science profile, specialization: Political Science (1998) and in Legal Sciences profile, specialization: Law (2004). She obtained the PhD in International Relations Specialty, in 2011, at Babes-Bolyai University of Cluj-Napoca, Romania. She participated at many national and international conferences; some of the recent event: she was invited at Brussels, Belgium (on October 2018) as Chair at the Symposium: Protecting Migrant Children and Unaccompanied Minors in the EU: Developing a Co-ordinated Approach to the Emerging Crisis (organized by Public Policy Exchange) and she participated as moderator at the 16th International Conference on Social Sciences organized by ICSS XVI and EUSER at Paris, France on November 2018. She teaches Sociology of International Relations, Political Sociology, Political Doctrines. Her recent books: Cultural $P R \&$ Creative Destination Branding. Cultural experiences and branding case studies in Italy \& Greece. Creative communication solution for cultural institu- 
tions (2020, coordinator); Opposition and Solidarity in Communism (2018, coordinator); European Union Diplomacy and the Middle East Crises at the Beginning of 21st Century (2016, author); she published on the last 10 years more than 20 articles.

\section{REFERENCES}

ABRIC, J.-C., 1994: Pratiques Sociales et Représentations. Paris: PUF.

ANDERSÉN, J. - ANDERSÉN, A., 2014: Deconstructing Resistance to Organizational Change: A Social Representation Theory Approach. International Journal of Organizational Analysis 22(3): 355-342.

DOI: https://doi.org/10.1108/JJOA-04-2012-0582.

BAR-TAL, D., 2014: Collective Memory as Social Representations. Papers on Social Representations 23: 5.1-5.26. Available online: https://psr.iscte-iul.pt/index.php/ PSR/ article/view/295/256 (accessed on 18 April 2021).

BALFOUR, B. - FORTUNATO, M. W. P. - ALTER, T. R., 2018: The Creative Fire: An Interactional Framework for Rural Arts-Based Development. Journal of Rural Studies 63: 229239. https://doi.org/229-239. 10.1016/j.jrurstud.2016.11.002.

BOLBORICI, A.-M., 2017: The Role and Importance of Information Sources. Case Study: The European Union's Diplomacy and the Middle East Crisis at the Beginning of the 21st Century. In Repanovici, A. - Koukourakis, M. - Khecyoyan, T. (eds.): Power in Communication, Sociology and Technology. Budapest: Trivent, p. 47-53. https://doi.org/10.22618/TP.PCMS.20181.156007.

BRATU, S., 2014: The Importance of Communication in the Production of Social Representations. Contemporary Readings in Law and Social Justice 6(1): 650-655.

BRAUN, V. - CLARKE, V., 2006: Using Thematic Analysis in Psychology. Qualitative Research in Psychology 3(2): 77-101. DOI: https://doi.org/10.1191/1478088706qp063oa.

BRUNNBAUER, U., 2012: Remembering Communism During and After Communism. Contemporary European History 21(3): 493-505. https://doi.org/ 10.1017/S0960777312000318.

CARRETERO, M., 2017: The Teaching of Recent and Violent Conflicts as Challenges for History Education. In: Psaltis, C. - Carretero, M. - Čehajić-Clancy, S. (eds.): History Education and Conflict Transformation. London: Palgrave Macmillan, p. 341-377. https://doi.org/10.1007/978-3-319-54681-0_14.

CHELCEA, S., 1996: Memoria socială - organizarea și reorganizarea ei. In: Neculau, A. (ed.): Psihologie socială. Aspecte contemporane. Iași: Polirom, p. 109-122.

CIOBANU, M., 2015: Remembering the Romanian Anti-Communist Armed Resistance: An Analysis of Local Lived Experience. Eurostudia 10(1): 105-123. https://doi.org/10.7202/1033884ar, 105-123.

CLARKE, D., 2014: Comunism and Memory Politics in the European Union. Central Europe 12(1): 99-114. https://doi.org/10.1179/1479096314Z.00000000018.

CIOROIANU, A., 2005: Pe umerii lui Marx. O introducere în istoria comunismului românesc. Bucurețti: Curtea Veche.

COJA, I., 2015: Dincolo de Nürnberg. Art-Emis Academy. Avaible online: https://www.artemis.ro/analize/dincolo-de-nurnberg (accessed on 10 September 2020).

COMAN, O., 2004: Rezistenţa din munţii României, o formă de alteritate faţă de regimul comunist în perioada 1944 - 1958. Available online: http://www.com unism. ro /fisiere/cercetatori/texte\%20PDF/coman.pdf (accessed on 12 May 2020). 
COMISIA prezidenţială pentru analiza dictaturii comuniste din România, 2006: Raport final. Available online: https://www.wilsoncenter.org/sites/default/files/media/docu ments/article/RAPORT\%20FINAL_\%20CADCR.pdf (accessed on 15 September 2020).

DELETANT, D., 2001: Teroarea comunistă în România. Gheorghiu-Dej şi statul poliţienesc, 1948 - 1965. Iaşi: Polirom.

DOBRINCU, D., 2007: Rezistenţa armată anticomunistă din Munţii Făgăraş - versantul nordic. „Grupul carpatic făgărăşan” / Grupul Ion Gavrilă (1949/1950-1955/1956). Anuarul Institutului de Istorie «G. Bariţiu» din Cluj-Napoca XLVI: 433-502.

FISHEL, S., 2015: Remembering Nukes: Collective Memories and Countering State History. Critical Military Studies 1(2): 131-144. https://doi.org/10.1080/23337486.2015.1050267.

FOGU, C. - KANSTEINER, W., 2006: The Politics of Memory and the Poetics of History. In: Lebow, R. N. - Kansteiner, W. - Fogu, C. (eds.): The Politics of Memory in Postwar Europe. Durham and London: Duke University Press. Pp. 284-310. https://doi.org/10.2307/j.ctv11cw204.12.

GAVRILĂ OGORANU, I., 2004: Brazii se frâng, dar nu se îndoiesc. Vol. 4. Făgăraş: Mesagerul de Făgăraș.

GOLDEN, C., 2005: Where Does Memory Reside, and Why Isn't It History. American Anthropologist 107(2): 270-274. https://doi.org/10.1525/aa.2005.107.2.270.

GRØDELAND, A., 2015: Perceptions of Civil Rights, Security and the "War on Terror": East and West Compared. Communist and Post-Communist Studies 48(4): 317-335. https://doi.org/10.1016/j.postcomstud.2015.10.003.

HALBWACHS, M., 1958: La mémoire collective. Paris: PUF.

HAȘU, I., 2017: Demonizing Armed Anti-Communist Resistance: The Făgăraș Group in the Securitate Files. Archiva Moldaviae 9: 245-272.

HERSENI, T., 1977: Forme străvechi de cultură poporană românească : studiu de paleoetnografie a cetelor de feciori din Țara Oltului. Cluj-Napoca: Dacia.

IONIȚOIU, C., 1993: Rezistenţa anticomunistă din munţii României, 1946 - 1958. Bucharest: Gândirea Românească.

KANSTEINER, W., 2006: Losing the War, Winning the Memory Battle: The Legacy of Nazism, World War II, and the Holocaust in the Federal Republic of Germany. In: Lebow, R. N. Kansteiner, W. - Fogu, C. (eds.): The Politics of Memory in Postwar Europe. Durham and London: Duke University Press. Pp. 102-146. https://doi.org/10.1215/9780822388333-004.

KASAMARA, V. - SOROKINA, A., 2015: Post-Soviet Collective Memory: Russian Youths about Soviet Past. Communist and Post-Communist Studies 48(2-3):137-145. https://doi.org/10.1016/j.postcomstud.2015.06.003.

LAMBEK, M., 2003: Memory in a Maussian Universe. In: Radstone, S. - Hodgkin, K. (eds.): Regimes of Memory. London: Routledge. Pp. 202-216.

LIICEANU, A., 2003: Rănile memoriei - Nucșoara și rezistența din munți. Iași: Polirom.

MIHALACHE, C., 2012: History Education Today: To Fear or Enjoy Meeting the Past. A Case Study: Romania. Procedia - Social and Behavioral Sciences 46: 1974-1977. https://doi.org/10.1016/j.sbspro.2012.05.413.

MIHALCEA, A. - STĂNESCU, M., 2014: 50 de ani de la eliberarea deţinuţilor politici anticomunişti. In: Revista 22. Available online: https://revista22.ro/eseu/alexandru-mihalcea-simirel-stanescu/50-de-ani-de-la-eliberarea-de355inu355ilor-politici-anticomuni351ti (accessed on 14 May 2020).

MIROIU, A., 2014: Military Operations in Romanian Anti-Partisan Warfare, 1944 - 1958. Studies in Conflict \& Terrorism 37(2): 185-197. https://doi.org/10.1080/09592318.2014.982884.

MOSCOVICI, S., 1973: Foreword. In: Herzlich, C. (ed.): Health and illness: A social psychological analysis. London: Academic Press. Pp. ix-xiv.

MOSCOVICI, S., 1976: La psychanalyse, son image et son public. Paris: PUF. 
NECULAU, A., 1996: Reprezentările sociale - dezvoltări actuale. In: Neculau, A. (ed.): Psihologie socială. Aspecte contemporane. Iași: Polirom. Pp. 34-51.

NORA, P., 1989: Between Memory and History: Les Lieux de Mémoire. Representations 26, Special Issue: Memory and Counter-Memory. Pp. 7-24. https://doi.org/10.2307/2928520.

PALMBERGER, M., 2016: How Generations Remember.Conflicting Histories and Shared Memories in Post-War Bosnia and Herzegovina. London: Palgrave Macmillan.

PETRESCU, R., 2012: Haiducii Muscelului, mişcarea de rezistenţă a colonelului Arsenescu. Preoţii colonelului Arsenescu. Historia 121(1): 52-55.

PSALTIS, C. - CARRETERO, M. - ČEHAJIĆ-CLANCY, S., 2017: Conflict Transformation and History Teaching: Social Psychological Theory and Its Contributions. In: Psaltis, C. Carretero, M. - Čehajić-Clancy, S. (eds.): History Education and Conflict Transformation. London: Palgrave Macmillan. https://doi.org/10.1007/978-3-319-54681-0_1.

PUSCA, A., 2014: Looking Back: Communist Melancholia and Post-Socialist Pains. Journal of International Relations and Development 17(3): 425-437. https://doi.org/10.1057/jird.2013.11.

ROTARIU, T. - ILUT,, P., 2001: Ancheta sociologica și sondajul de opinie. Iași: Polirom.

SOREA, D. - BORCOMAN, M. - RĂȚULEA, G., 2011: Factors that Influence Students' Attitude Towards Copying and Plagiarism. In: Murzea, C. I. - Repanovici, A. (eds.): Legal Practice and International Laws. WSEAS Press. Pp. 315-318.

SOREA, D. - CSESZNEK, C., 2020: The Groups of Caroling Lads from Făgăraș Land (Romania) as Niche Tourism Resource. Sustainability 12(11): 4577. https://doi.org/10.3390/su12114577.

SOREA, D. - REPANOVICI, A., 2020: Project-Based Learning and its Contribution to Avoid Plagiarism of University Students. Investigación bibliotecológica 34(85): 155-178. https://doi.org/10.22201/iibi.24488321xe.2020.85.58241.

SOREA, D. - ROȘCULET, G. - BOLBORICI, A-M., 2021: Readymade Solutions and Students' Appetite for Plagiarism as Challenges for Online Learning. Sustainability 13(7): 3861. https://doi.org/10.3390/su13073861.

ŠUBRT, J., 2011: Antinomie sociální paměti. Sociológia 43(2): 133-157.

VOICU-ARNĂUȚOIU, I. R., 2009: Luptătorii din munți. Toma Arnăuțoiu- Grupul de la Nucșoara. Bucharest: Vremea.

WYDRA, H., 2012: The Power of Symbols-Communism and Beyond. International Journal of Politics, Culture and Society 25(1-3): 49-69. https://doi.org/10.1007/s10767-011-9116-x.

ZEMBYLAS, M. - KARAHASAN, H., 2017: Formal and Non-Formal Reform Efforts of History Teaching in Cyprus: Openings and Closures for Dangerous Memories and Reconciliation Pedagogies. In: Psaltis, C. - Carretero, M. - Čehajić-Clancy, S. (eds.): History Education and Conflict Transformation. London: Palgrave Macmillan. Pp. 321-339. https://doi.org/10.1007/978-3-319-54681-0_13. 